\title{
Centella asiatica ethanol extract increases hippocampal brain derived neurotrophic factor in male Wistar rats
}

\author{
Astri Handayani*,**, Sophie Yolanda***, and Ria Kodariah****
}

\begin{abstract}
\section{BACKGROUND}

Synaptic plasticity, which primarily takes place in the hippocampus, is the molecular basis of long- term memory formation. Brain derived neurotrophic factor (BDNF), a member of the neurotrophin family, plays a significant role in synaptic plasticity and memory formation. When BDNF is released, it binds to its receptor and activates various intracellular signal transduction pathways leading to synaptic plasticity. Several methods to improve memory function in humans have been studied, one of which is the use of herbal compounds, such as Centella asiatica (CeA), an herbaceous plant that has been used for improving memory. This study aims to examine the effects of CeA ethanol extract on BDNF protein expression in the CA1 hippocampal region in adult male rats.
\end{abstract}

\section{METHODS}

A randomized experimental design was performed involving 18 adult male Wistar rats. The rats were randomized into three groups: one control/ distilled water group and two groups treated with doses of CeA ethanol extract of $300 \mathrm{mg} / \mathrm{kgBW}(\mathrm{CeA} 300)$ and $600 \mathrm{mg} / \mathrm{kgBW}$ (CeA600), respectively. $\mathrm{CeA}$ ethanol extract was administered orally for 28 consecutive days with weekly weight-adjusted dose. After 28 days, the rats were decapitated, and the hippocampus was isolated from the brain. BDNF protein expression was assessed using immunohistochemistry. Data was analyzed using Kruskal-Wallis test and continued with post-hoc analysis.

\section{RESULTS}

There was a significant increase in BDNF protein expression in the CeA600 group compared to the control group $(\mathrm{p}<0.001)$.

\section{CONCLUSION}

Administration of CeA ethanol extract increased BDNF protein expression in the CA1 hippocampal region of adult male rats.

Keywords: BDNF, Centella asiatica, hippocampus, synaptic plasticity, adult male rats
*Department of Physiology,

Faculty of Medicine,

Trisakti University

**Graduate Student, Biomedical Science,

Faculty of Medicine,

University of Indonesia

***Department of Physiology,

Faculty of Medicine,

University of Indonesia

****Department of Pathological

Anatomy, Faculty of Medicine,

University of Indonesia

\section{Correspondence:}

dr. Sophie Yolanda, M.Biomed

Department of Physiology,

Faculty of Medicine,

University of Indonesia,

Jalan Salemba Raya No 6 Jakarta

Phone: +62 816-1958-138

Email: sophie.y@ui.ac.id

Date of first submission, June 21, 2018

Date of final revised submission, August 7, 2018

Date of acceptance, August 10, 2018

This open access article is distributed under a Creative Commons AttributionNon Commercial-Share Alike 4.0

International License

Cite this article as: Handayani A, Yolanda S, Kodariah R. Centella asiatica ethanol extract increases hippocampal brain derived neurotrophic factor in male Wistar rats. Univ Med 2018;37: 143-9. doi: 10.18051/UnivMed.2018. v37.143-149 


\section{INTRODUCTION}

As humans grow old, memory function declines. Memory formation is a process based on activity-dependent modification of synapses, also known as synaptic plasticity. It is a condition by which the brain builds neuronal circuits during development and controls cognitive function and complex behaviors in the adult. ${ }^{(1)}$ Synaptic plasticity is input-specific or synapse-specific where structural and functional modification occurs only in synapses that experience changes in activity. Activity-dependent changes in synaptic strength are considered to be the underlying mechanism of learning and memory. Besides structural changes happening in hippocampal neuronal cells, molecular substances also affect activity-dependent synaptic strength and alter learning and memory. ${ }^{(2,3)}$ One of these molecular substances is brain derived neurotrophic factor (BDNF). This factor was first purified from the mammalian brain based on its survival-promoting action on dorsal root ganglion cells and was classified as the second member of the neurotrophin family of growth factors. ${ }^{(4)}$ Neurotrophins are a family of secreted proteins that have emerged as important regulators of synaptic plasticity. Neurotrophins are also required for the development of the nervous system of vertebrates. The family also includes neurotrophin 3 (NT3), neurotrophin-4/5, neurotrophin-6 and neurotrophin-7. Brain derived neurotrophic factor is the member of the neurotrophin family that has been extensively studied and has been shown to modulate the development and function of synapses. Some studies show that BDNF facilitates both earlyphase and late-phase long-term potentiation (LTP). ${ }^{(5)}$

Brain derived neurotrophic factor is a small dimeric protein, which will bind and activate, both pre- and post-synaptically, two different transmembrane receptor proteins, the tropomyosin related kinase-B (TrkB) with high affinity and the pan neurotrophin receptor $\mathrm{p} 75^{\mathrm{NTR}}$ with low affinity. Brain derived neurotrophic factor and TrkB are widely distributed across subregions of the hippocampus and the adult forebrain. ${ }^{(4,6)}$ Tropomyosin related kinase-B activation by BDNF follows the general pathway for tyrosine kinases receptors and initiates three major cascades of signaling pathways: phospholipase $\mathrm{C} \gamma$ (PLC $\gamma$ ), phosphatidylinositol3-kinase $\left(\mathrm{PI}_{3} \mathrm{~K}\right)$ and the cascade regulated by extracellular signal-regulated kinase (ERK), a member of the mitogen-activated protein kinase (MAPK) family. ${ }^{(7)}$ Several methods to increase BDNF expression have been studied, such as physical exercise and herbal supplementation, e.g. with Centella asiatica (CeA). ${ }^{(8,9)}$

Centella asiatica is a herbaceous plant, commonly found in South-East Asian countries. The plant grows well in high-humidity areas and is distributed from the subtropics to the tropics. ${ }^{(10)}$ Centella asiatica has been widely used for centuries as a medicinal herbal plant, for various purposes, such as wound healing, brain-stimulating effects, treatment of hypertension, microangiopathy, gastric ulcer, and as a potent antioxidant. ${ }^{(11,12)}$ Some important chemical constituents found in $\mathrm{Ce} \mathrm{A}$ are triterpenoids and flavonoids. ${ }^{(2,13)}$ Other studies also highlighted asiaticoside and asiatic acid which are part of the triterpenoids compounds in CeA. ${ }^{(14,15)}$ Centella asiatica has been shown to be very useful in improving learning and memory; it is also used as a tonic to promote brain growth and improve memory. Studies showed that administration of CeA will enhance neuronal dendrites in rats undergoing growth spurts ${ }^{(16,17)}$ and shows anti-inflammatory effects on hippocampal neuronal cells. ${ }^{(18)}$ Centella asiatica also functions as antioxidant, helps with the wound healing process, and is able to treat hypertensive microangiopathy. ${ }^{(19)}$ Centella asiatica also has neuroprotective effects by modulating antioxidant and mitochondrial pathways, and improving cognitive function in mice. ${ }^{(20,21)}$

A previous study by Sari et al..$^{(2)}$ showed that administration of CeA ethanol extract at doses of $300 \mathrm{mg} / \mathrm{kgBW}$ and $600 \mathrm{mg} / \mathrm{kgBW}$ increases 
BDNF level in serum. Kamelia et al. ${ }^{(12)}$ showed that administration of $\mathrm{CeA}$ leaf extract increases neurogenesis and BDNF levels in hippocampal cell culture from 2-week-old mice. Mirza et al. ${ }^{(22)}$ also showed that administration of $\mathrm{CeA}$ ethanol extract for 8 weeks will increase cognitive function in 2-month-old male Wistar rats. These previous studies have shown that CeA extract is capable of increasing BDNF levels in the blood and in hippocampal cell culture, and even improve cognitive and memory functions, but they have not showed the effect of CeA ethanol extract on BDNF protein expression in the hippocampus of adult rats. Our research used male Wistar rats of 6 months of age, which is the equivalent of 18 years in humans. ${ }^{(23)}$ The neurodegenerative process starts when humans reach the age of 18 years, thus it is necessary to take preventive action to reduce the decline of memory function. This study aimed to assess the effect of CeA ethanol extract on the expression of hippocampal BDNF protein that plays a key role in synaptic plasticity and memory function.

\section{METHODS}

\section{Research Design}

Our research was an in-vivo experimental study, conducted at the Laboratory of Pathological Anatomy, Department of Pathological Anatomy, Faculty of Medicine, Universitas Indonesia from June until September 2017. This experiment was part of a larger research project that tried to explore the potential effect of CeA ethanol extract on proteins that play a role in synaptic plasticity, one of them being BDNF.

\section{Animals}

The experiments were conducted using eighteen 6-month-old adult male Wistar rats weighing 300-400 grams, that were bred at Biofarma Laboratory, Bandung. The subjects were divided randomly into three groups: one control/distilled water group and two groups treated with different doses $(\mathrm{mg} / \mathrm{kg})$ of CeA ethanol extract: $300 \mathrm{mg} / \mathrm{kgBW}(\mathrm{CeA} 300)$ and 600 $\mathrm{mg} / \mathrm{kgBW}(\mathrm{CeA} 600){ }^{(2)}$ Two animals were placed in the same cage with food and water available ad libitum and maintained on a 12-hour light and 12-hour dark cycle. The room temperature was maintained at $23 \pm 1{ }^{\circ} \mathrm{C}$. Animals were acclimatized for one week before treatment, followed by oral administration of CeA ethanol extract and hippocampal isolation at the end of the treatment.

\section{Sample size determination}

The sample size was calculated using the Mead equation reference with the total number of animal subjects ranging from 13 to 23 subjects. ${ }^{(24)}$ This experiment used 6 subjects in each group, with a total of 18 animals for 3 groups.

\section{Intervention}

Centella asiatica plants were obtained from Cikabayan Field, Bogor Agricultural Institute. The extraction and formulation of $\mathrm{CeA}$ was performed at the Spices and Medicinal Plant Research Station (Balai Penelitian Tanaman Rempah dan Obat, Balittro), Bogor. In order to prepare the doses of $300 \mathrm{mg} / \mathrm{kgBW}$ and $600 \mathrm{mg} /$ $\mathrm{kgBW}$, the CeA ethanol extract was freshly diluted with sterile distilled water. The CeA ethanol extract was administered orally for 28 consecutive days with weekly weight-adjusted dose.

\section{Measurement of BDNF protein expression}

After a 28-day-administration period of CeA ethanol extract, the rats were decapitated, and the hippocampal tissue was isolated. BDNF protein expression was assessed with an immunohistochemical technique using anti-BDNF antibody (Abcam, EPR1292). BDNF protein expression was then calculated using the ImageJ program.

\section{Statistical analysis}

Between-group differences were analyzed by Kruskal-Wallis test and continued with post hoc analysis using the SPSS 22.0 software. The differences were considered statistically significant at a $\mathrm{p}$ value of $<0.05$. 


\section{Ethical Clearance}

The experimental protocols were approved by the Health Research Ethics Committee, Faculty of Medicine, Universitas Indonesia, Cipto Mangunkusumo Hospital under No. 824/ UN.2F1/ETIK/2016.

\section{RESULTS}

The results of the immunohistochemical assay are presented in Figure 1. Cells expressing BDNF show a brownish color. It is apparent that BDNF protein expression level in the control group (Figure 1.B) was the lowest of the three groups. The CeA300 group showed a higher expression level of BDNF (Figure 1.C) compared to the control group (Figure 1.D) The CeA600 group showed the strongest expression level of BDNF in the CA1 region of the hippocampus. Quantitatively, BDNF protein expression of each treatment group is presented in Figure 2 as mean optical density score. Statistical analysis was conducted to identify any significant difference in each group using Kruskal-Wallis test and continued with MannWhitney post hoc analysis.

(Figure 2)

Figure 2 shows that the control group has the lowest level of BDNF protein expression (1.94 \pm 041$)$ compared to groups CeA300 (2.22 $\pm 0.11)$ and CeA600 (2.79 \pm 0.08$)$. Post hoc analysis showed that there was a significant difference in BDNF protein expression level between the control group and the CeA600 group $(p=0.000)$ and also between the CeA300 group and the CeA600 group ( $\mathrm{p}=0.000$ ).
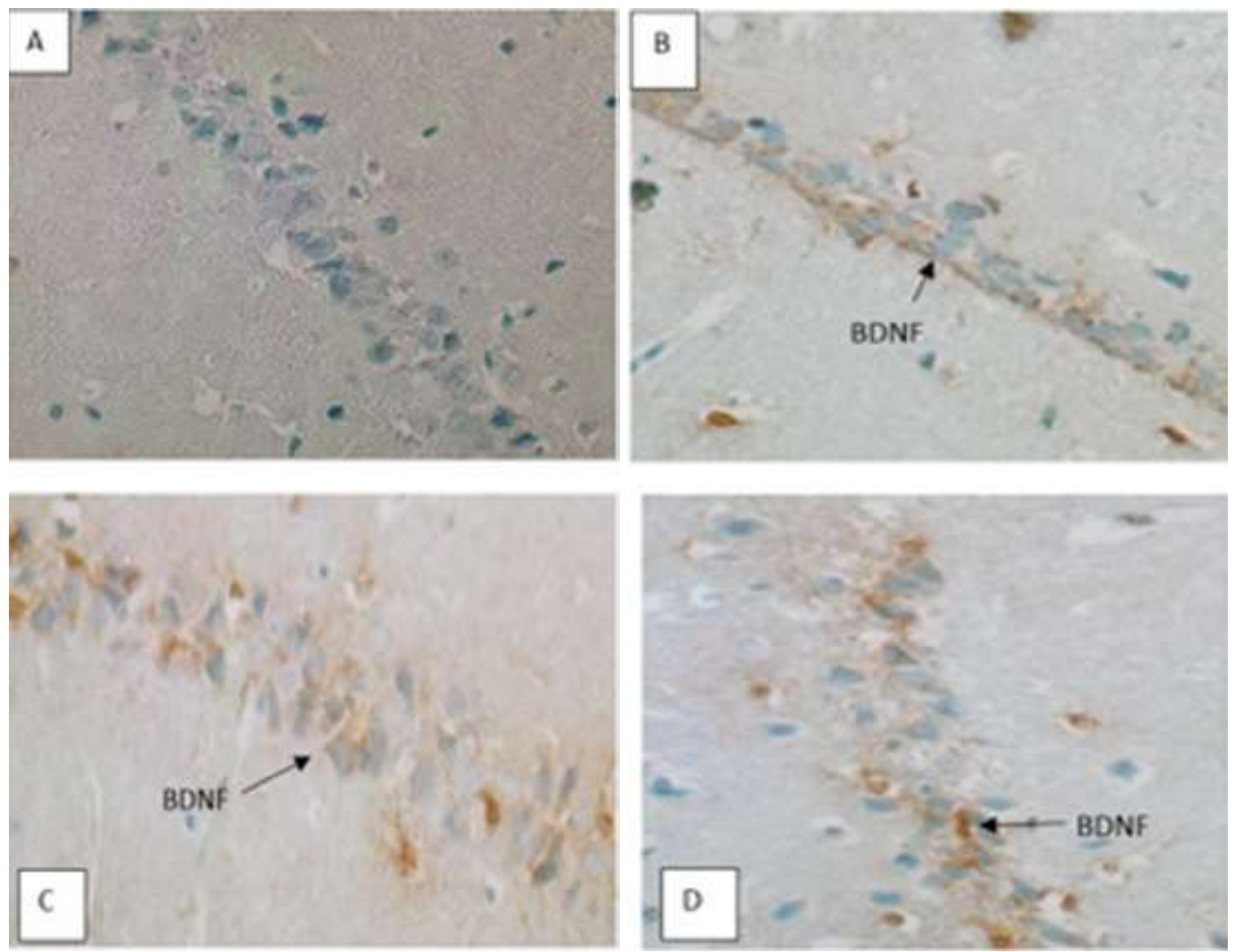

Figure 1. BDNF protein expression in hippocampal CA1 region using immunohistochemical staining: A. Hippocampal CA1 region in negative control group; B. Hippocampal CA1 region in control group, C. Hippocampal CA1 region in CeA300 group; D. Hippocampal CA1 region in CeA600 group 


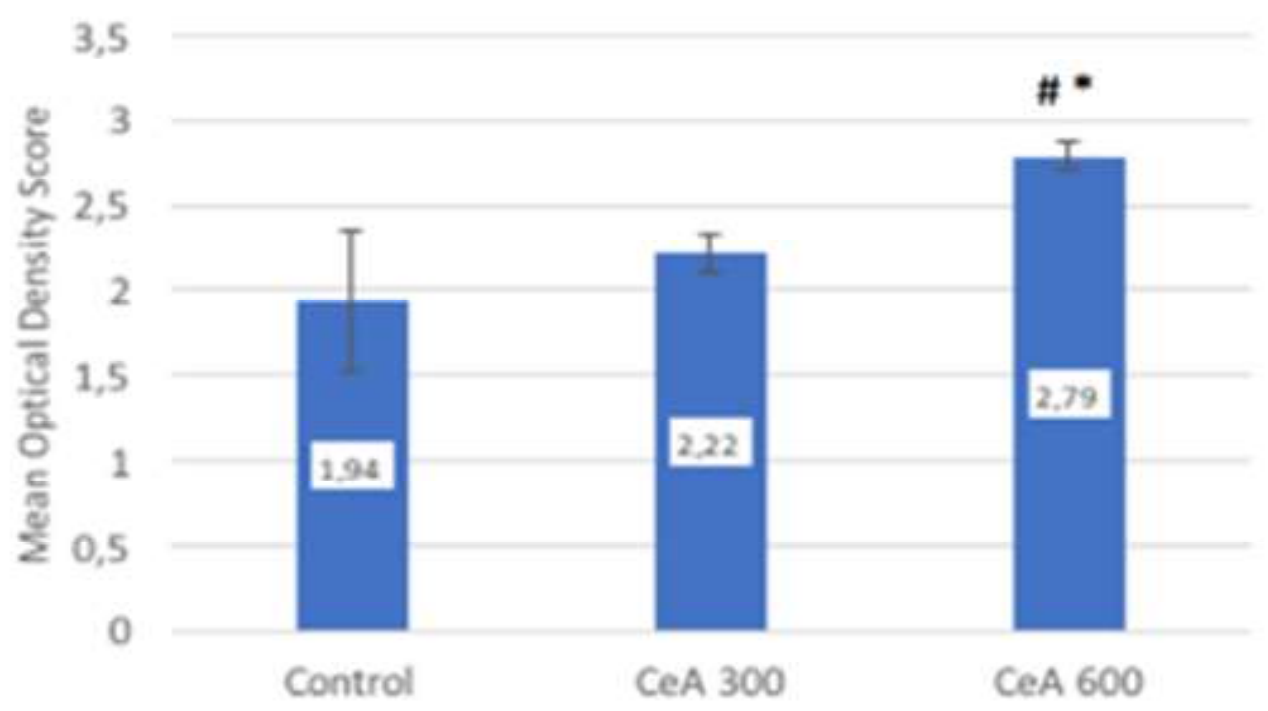

Figure 2. Mean optical density score of BDNF protein immunohistochemistry. Kruskal-Wallis test $\mathrm{p}<0.001, \# \mathrm{p}<0.001$ vs CeA300 group, ${ }^{*} \mathrm{p}<0.001$ vs control group

\section{DISCUSSION}

Brain derived neurotrophic factor, a member of the neurotrophin family, is known as the main regulator in synaptic plasticity. ${ }^{(5,6,25)}$ It is also known as a key molecule that has an important role in neuronal differentiation, neuronal survival, and formation of synapses. ${ }^{(26,27)}$

Centella asiatica extract has been shown to increase learning and memory. ${ }^{(28)}$ Memory is enhanced through facilitation of memory retention, the longer the retention of the memory the better it will be able to increase cognitive function. ${ }^{(29)}$ The memory retention process involves growth and arborization of dendrites in hippocampal neurons. ${ }^{(16,17)}$ Learning and memory improvement might be connected with the antioxidant, antiinflammatory, and neuroprotective activities of CeA. ${ }^{(22)}$ Centella asiatica has antioxidant potential, thus it can act as a neuroprotector and has been proven to be effective in protecting the rat brain against age-related oxidative damage. ${ }^{(30)}$

Our study showed that administration of $\mathrm{CeA}$ ethanol extract increases BDNF protein expression in the hippocampus. Centella asiatica significantly increased the BDNF protein expression in the CeA600 group (compared to the control group, Figure 2). This result is consistent with the results of previous studies conducted by Sari et al., ${ }^{(2)}$ Kamelia et al., ${ }^{(12)}$ and Mirza et al. ${ }^{(22)}$

Some of the active ingredients contained in $\mathrm{CeA}$ are the triterpenoids and flavonoids. Asiatic acid and asiaticoside have also been highlighted and are parts of the triterpenoids of CeA. ${ }^{(28,30,31)}$ Flavonoids in CeA in previous studies have been shown to pass through the blood-brain barrier and enhance cortical blood flow. Increased cerebrovascular function, especially in the hippocampus, a brain region important for memory, may facilitate adult neurogenesis. The enhancement of both short-term or long-term memory is controlled at the molecular level. Four signaling pathways controlling this enhancement process are cAMP-dependent protein kinase (protein kinase A), calcium-calmodulin kinase, protein kinase $\mathrm{C}$, and mitogen-activated protein kinase (MAPK). ${ }^{(32,33)}$ All four pathways converge to signal to the cAMP-response element-binding protein (CREB), a transcription factor which binds to the promoter regions of many genes associated with memory and synaptic plasticity. With their ability to modulate CREB, flavonoids may modulate the expression of neuronal genes which contain cAMP-response element (CRE) sequences in their promoter region. One such a neuronal gene is the BDNF gene. ${ }^{(33)}$ By increasing the activity of CREB, BDNF protein expression 
in the hippocampus will increase. ${ }^{(33,34)}$ When $\mathrm{BDNF}$ is released from the presynaptic region, it will bind to its receptor tyrosine kinase B (TrkB) and induce various intracellular signaling pathways.

Our study was able to demonstrate higher BDNF protein expression in the CA1 hippocampal region of the treated groups, but this higher BDNF protein expression does not equate to its activity of binding to its receptor TrkB. Thus, further exploration on BDNF activity, its mechanism of binding to its TrkB receptor and its downstream signaling pathway is needed for further understanding about synaptic plasticity. Next, a study on rats with induced neurodegeneration will also be useful to observe the potential role of $\mathrm{CeA}$ in neuroregenerative medicine.

\section{CONCLUSIONS}

Administration of $\mathrm{CeA}$ ethanol extract increases BDNF protein expression in the CA1 hippocampal region. Thus, the use of $\mathrm{CeA}$ is promising for the treatment of neurodegenerative disorders.

\section{CONFLICT OF INTEREST}

Competing interests: no relevant disclosures.

\section{FUNDING DISCLOSURE}

There is no financial conflict of interest to disclose.

\section{ACKNOWLEDGMENT}

This research was partly funded by Dana Beasiswa Tesis \& Disertasi LPDP Kemenkeu 2017.

\section{CONTRIBUTORS}

AH and SY contributed to the research concept and design of the study. RK contributed to drafting the manuscript. AH contributed to data acquisition and SY to data analysis and interpretation. All authors read and approved the final manuscript.

\section{REFERENCES}

1. Takeuchi T, Duszkiewicz AJ, Morris RGM. The synaptic plasticity and memory hypothesis: encoding, storage and persistence. Philos Trans R Soc B Biol Sci 2013;369:20130288. doi: 10.1098/ rstb.2013.0288.

2. Sari DCR, Aswin S, Susilowati R, et al. Ethanol extracts of Centella asiatica leaf improves memory performance in rats after chronic stress via reducing nitric oxide and increasing brainderived neurotrophic factor (BDNF) concentration. GSTF J Psychol 2014;1:9. doi: 10.7603/s40790-014-0009-0.

3. Amin SN, Younan SM, Youssef MF, et al. A histological and functional study on hippocampal formation of normal and diabetic rats. F1000Research 2013;2:151. doi: 10.12688/ f1000research.2-151.v1.

4. Cunha C, Brambilla R, Thomas KL. A simple role for BDNF in learning and memory? Front Mol Neurosci 2010;3:1-14. doi: 10.3389/neuro.02. 001.2010.

5. Choo M, Miyazaki T, Yamazaki M, et al. Retrograde BDNF to TrkB signaling promotes synapse elimination in the developing cerebellum. Nat Commun 2017;8:195. doi: 10.1038/s41467-01700260-w.

6. Guo W, Ji Y, Wang S, et al. Neuronal activity alters BDNF-TrkB signaling kinetics and downstream functions. J Cell Sci 2014;127(Pt 10):2249-60. doi: 10.1242/jcs.139964.

7. Bathina S, Das UN. Brain-derived neurotrophic factor and its clinical implications. Arch Med Sci 2015;11:1164-78. doi: 10.5114/aoms.2015.56342.

8. Sleiman SF, Henry J, Al-Haddad R, et al. Exercise promotes the expression of brain derived neurotrophic factor (BDNF) through the action of the ketone body $\beta$-hydroxybutyrate. Elife 2016; 5:e15092. doi: 10.7554/eLife.15092.

9. Chiu J, Chen F, Tsai Y, et al. Effects of Chinese medicinal herbs on expression of brain-derived neurotrophic factor (BDNF) and its interaction with human breast cancer MDA-MB-231 cells and endothelial HUVECs. BMC Complement Altern Med 2017;17:401. doi: 10.1186/s12906-017-19097.

10. Orhan IE. Centella asiatica (L.) Urban: from traditional medicine to modern medicine with neuroprotective potential. Evid Based 
Complement Altern Med 2012. Article ID 946259, 8 pages. doi: 10.1155/2012/946259.

11. Haleagrahara N, Ponnusamy K. Neuroprotective effect of Centella asiatica extract (CAE) on experimentally induced parkinsonism in aged Sprague-Dawley rats. J Toxicol Sci 2010;35:41-7. https://doi.org/10.2131/jts.35.41.

12. Kamelia E, Miko H, Karo MB, et al. The effect of leaf extract of Centella asiatica on neurogenesis and Bdnf level in hippocampus cell culture in young mice. Clin Neurol Neurosci 2017;1:14-9. doi: 10.11648/j.cnn.20170101.14.

13. Khotimah H, Sumitro SB, Mulyohadi A. Standardized Centella asiatica increased brain derived neurotrophic factor and decreased apoptosis of dopaminergic neuron in rotenone induced zebrafish. GSTF J Psychol 2015;2:8-15. doi: $10.5176 / 2345-7872$.

14. Lokanathan Y, Omar N, Ahmad Puzi NN, et al. Recent updates in neuroprotective and neuroregenerative potential of Centella asiatica. Malaysian J Med Sci 2016;23:4-14.

15. Krishnamurthy RG, Senut M, Zemke D, et al. Asiatic acid, a pentacyclic triterpene from Centella asiatica, is neuroprotective in a mouse model of focal cerebral ischemia. J Neurosci Res 2009; 87:2541-50. https://doi.org/10.1002/ jnr.22071.

16. Rao KGM, Rao SM, Rao SG. Centella asiatica (linn) induced behavioural changes during growth spurt period in neonatal rats. Neuroanatomy 2005;4:18-23.

17. Rao KGM, Rao SM, Rao SG. Centella asiatica leaf extract treatment during the growth spurt period enhances hippocampal CA3 neuronal dendritic arborization in rats. Evid Based Complement Alternat Med 2006;3:349-57. doi: 10.1093/ecam/nel024.

18. Hemamalini, Rao MS. Anti stress effect of Centella asiatica leaf extract on hippocampal CA3 neurons - a quantitative study. Int J Pharmacol Clin Sci 2013;2:25-32.

19. Gohil KJ, Patel JA, Gajjar AK. Pharmacological review on Centella asiatica: a potential herbal cure-all. Indian J Pharm Sci 2010;72: 546-56. doi: 10.4103/0250-474X.78519.

20. Gray NE, Harris CJ, Quinn JF, et al. Centella asiatica modulates antioxidant and mitochondrial pathways and improves cognitive function in mice. J Ethnopharmacol 2016;180:78-86. doi: 10.1016/j.jep.2016.01.013.

21. Loganathan C, Thayumanavan P. Asiatic acid prevents the quinolinic acid-induced oxidative stress and cognitive impairment. Metab Brain Dis 2018;33:151-9. doi: 10.1007/s11011-017-0143-9.
22. Mirza I, Riyadi H, Khomsan A, et al. The effect of ethanol extract of gotu kola leaf(Centella asiatica (L.) Urban) on hematological profile, activities, and cognitive function. J Kedokt Hewan 2013;7: 137-40.

23. Andreollo NA, Santos EF, Araujo MR, et al. Rat's age versus human's age: what is the relationship? Arq Bras Cir Dig 2012;25:49-51. doi: 10.1590/S0102 $-67202012000100011$.

24. Arifin WN, Zahiruddin WM. Sample size calculation in animal studies using resource equation approach. Malays J Med Sci 2017;24: 101-5. doi: 10.21315/mjms2017.24.5.11.

25. Leal G, Afonso PM, Salazar IL, et al. Regulation of hippocampal synaptic plasticity by BDNF. Brain Res 2015;1621:82-101. doi: 10.1016/j.brainres.2014. 10.019 .

26. Panja D, Bramham CR. BDNF mechanisms in late LTP formation: a synthesis and breakdown. Neuropharmacology 2014;76 Pt C:664-76. doi: 10.1016/j.neuropharm.2013.06.024.

27. Leal G, Comprido D, Duarte CB. BDNF-induced local protein synthesis and synaptic plasticity. Neuropharmacology 2014;76 Pt C:639-56. doi: 10.1016/j.neuropharm.2013.04.005.

28. Soumyanath A, Zhong YP, Henson E, et al. Centella asiatica extract improves behavioral deficits in a mouse model of Alzheimer's disease: investigation of a possible mechanism of action. Int J Alzheimer's Dis 2012, Article ID 381974, 9 pages. doi: 10.1155/2012/381974.

29. Jared SR. Enhancement of memory in rats with Centella asiatica. Biomed Res 2010;21:429-32.

30. Subathra M, Shila S, Devi MA, et al. Emerging role of Centella asiatica in improving age-related neurological antioxidant status. Exp Gerontol 2005;40:707-15. doi: 10.1016/j.exger.2005.06.001.

31. Nurlaily A, Noor Baitee AR, Musalmah M. Comparative antioxidant and anti-inflammatory activity of different extracts of Centella asiatica (L.) Urban and its active compounds, asiaticoside and madecassoside. Med Heal 2012;7:62-72.

32. Vauzour D, Vafeiadou K, Rodriguez-Mateor A, et al. The neuroprotective potential of flavonoids: a multiplicity of effects. Genes Nutr 2008;3:11526. doi: 10.1007/s12263-008-0091-4.

33. Spencer JPE. The interactions of flavonoids within neuronal signalling pathways. Genes Nutr 2007;2:257-73. doi: 10.1007/s12263-007-0056-Z.

34. Spencer JPE. Flavonoids: modulators of brain function? Br J Nutr 2008;99:60-77. doi: 10.1017/ S0007114508965776. 